\title{
丸棒鋼用自動磁粉探傷装置の開発
}

市岡雄二*

\section{Development of Automatic Fluorescent Magnetic Particle Inspection Equipment for Round Steel Bars}

\author{
Yuuji Ichioka
}

\begin{abstract}
Synopsis
Recently customers have required round steel bars assured of the surface integrity. In order to fulfil such requirement, a new quality assurance system has been developed and already installed in the shop. It consists of a computerized flaw detector through fluorescent magnetic particles and a fully automatic grinding machine.

At first the particle distribution is taken by CCD cameras. This image is processed and diagnosed by computers and then the surface defects are mapped out into the memory.

Later they are removed from the surface through a grinding machine controlled by the computer.

Employing the new system, round steel bars are guaranteed from the surface defects $0.1 \mathrm{~mm}$ or more deep.
\end{abstract}

\section{1.はじめに}

近年，黒皮圧延丸棒鋼用の渦流探侮法・漏洩磁 束探侮法など表面症自動探伤装置は検出性能・処 理速度などの面で急速に進歩し，品質保証の信頼 性・生産性向上に大きく奇与している。

しかしながら，表1に示すよらに需要家の品質 要求がますます多様化・高度化し，冷般材など過 酷な用途の素材については0.1mm 程度の浅い表 面疵さえ許容されなくなっている。そのため，検 出性能の面から旧来の磁粉探愎法による低能率な

1992年 7 月 29 日受付

“大同特殊鋼知多工場
目視検查を余儀なくされていた。

そこで大同特殊銅では，表面痽検出レベルの 最も優位な磁粉探仿法による自動化システムとこ れに接続する自動证取装直を開発し，高精度でか つ高能率な表面疵検査から症取までの自動システ ムを完成させだー吕本稿ではこの自動磁粉探侮・ 自動㿂取装嘈について報告する。

\section{2. 設偷概要}

\section{1 ラインレイアゥト}

図1に自動磁粉探侮装置及び前後装貫のレイフ ウトを示す。より高い表面疵の検出性能を得るた め, 探伤前にショットブラストによるスケール落 とし及び2ロール稪正機による曲り稪正を実施し 被険査材の表面性状を整えている。 
表 1 品質要求レベルの变化

\begin{tabular}{|c|c|c|c|c|}
\hline \multirow{2}{*}{ 項 } & \multirow{2}{*}{ 目 } & \multicolumn{2}{|c|}{ 要求レベル } & \multirow{2}{*}{ 備 } \\
\hline & & 従 & 現状(影む敞しいるの) & \\
\hline \multirow[t]{4}{*}{ 表面㖢 } & 冷温鏗品 & $0.20 \mathrm{~mm}$ 以下 & $0.10 \mathrm{~mm}$ 以下 & \multirow[t]{2}{*}{$\begin{array}{l}\text { 加工度向上 } \\
\text { 閉寋毀造化 } \\
\text { 精密毁造化 }\end{array}$} \\
\hline & 霓出鐉造品 & - & $0.10 \mathrm{~mm}$ 以下 & \\
\hline & 熱鍜品 & $0.30 \mathrm{~mm}$ 以下 & $0.15 \mathrm{~mm}$ 以下 & 精密熱鍛化 \\
\hline & 切削品 & 寸法公差内 & 寸法公差内 & $\longrightarrow$ \\
\hline
\end{tabular}

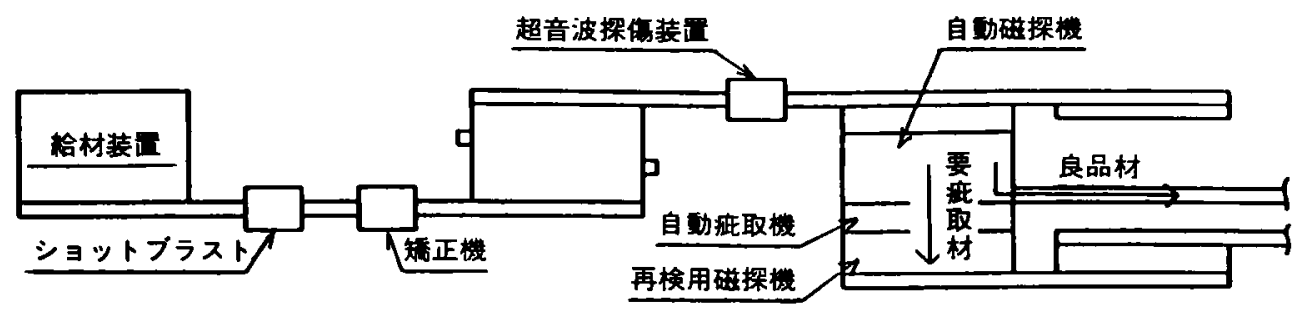

困1 ラインレイフウト

本自動磁粉探傹装置（以下自動磁探譏）は，磁 化部で化した被険查材を水洗後 CCD (Charge Coupled Device）カメラにより撮像し，この情報 を信号処理した後に自動瘷判定を行い，良品材と 要揤取材とに升別する。良品材はそのまま出荷検 查を実施し入庫となる。要症取材は本装固の直後 に配眉された自動瘷取置により廐を研削除去

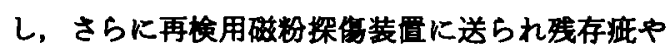
取り残し踓を目視検査により再検し，その後手直 しして出荷検查後入庫となる。

従来は能率の異なる個々の設備がハッッチ的に配 置されマテハンが多く物流を著しく阻害してい た。本ラインではショットブラスト，矯正機，超 音波探㥂機，自動磁探機，症取譏，再検用磁探機， 入庫までの全設備をフルライン化し，電算機によ るトラッキンクにより円滑な操業を実施してい る。

\section{2 自徝磁探機}

图 2 に示すよ5に自動磁探機・自動疵取機のシ ステム構成は機械系として磁化部・水洗部・疵見

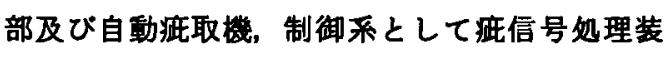
置・上位龟算機・シーケンサから構成される。本 装置はすなわち，表面症検査から疪取までの高精

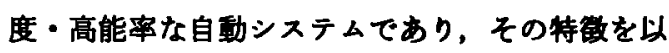
下に説明する（表 2 )。

\section{2 .1 化 部}

磁粉の付着状稳を均一化するため没清方式を採 用し，処理サイクル時間を短くするため連礼処理 が可能な回転円盤磁化方式を採用した（写具1）。 また，自勤磁探譏の疵検出性能を向上させるため 粗・細粒混合の高輝度特殊砤物の開発す手卦け実 用化した。

\subsection{2 水 洗 部}

水洗部は碳化部と同じ回伝円盤方式を採用する ことによりサイクルタイムの短樎を図った。さら に图 3 に示すよらに水洗処理することにより，被 検查材表面の肌荒れ部やスケール部に付着した磁 粉および磁粉液のしずくなど表面疵以外に付着し たノイズ磁の除去が可能となった。その結果飛 的に $S / N$ が向上し，過検出が減少した。 


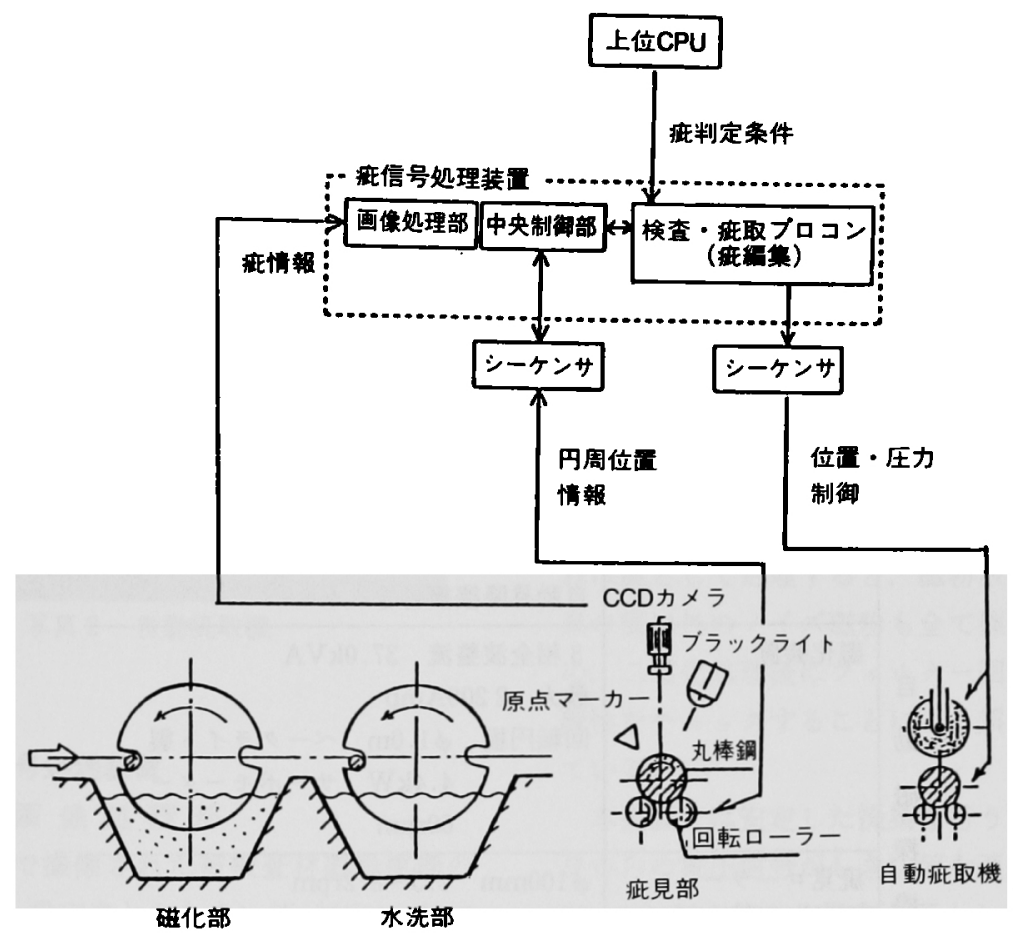

因2自動磁探機・自動疵取機のシステム

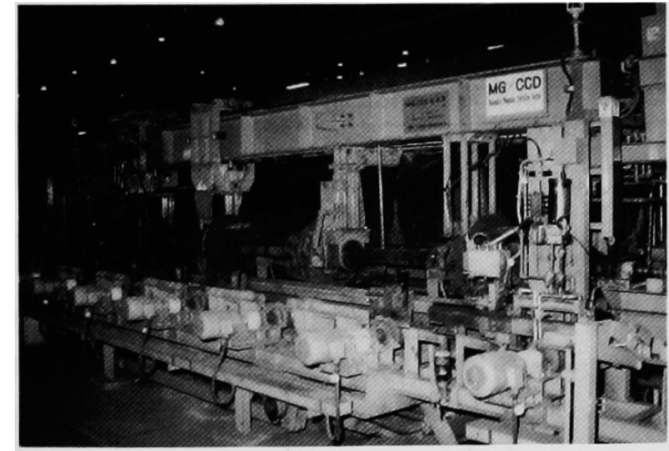

写真 1 自動磁探機概観

\subsection{3 煡 見 部}

疵見部はブラックライト(10台)， CCDカメラ (30台), 原点マーカー, 被検査材回転機構から成 る。

(1) カメラは240mmの有奻視野を持つCCD カメラを採用し，かつ被検查材のサイズに合わせ て焦点距離を一定にする自動高さ調整機構を装備 している。

（2）原点マーカーは被検査材の端面に蛍光ぺイ
ソトを用いて線状にマークする方式で，自動疪取 で必要な被検査材周方向の原点位首を決めるるの である。この原点マークは表面疵と同様に CCD カメラの原点マーク読み取りのため設定されたウ インドウ（電気マスク）から検出される。

（3）回転機構部では被検査材全周の表面を検査 するため被検査材を回伝させ, CCD カラで設定 したウインドウから疵を検出する。検出した疪の 周方向位置は原点マークを基準にパルスゼネレー ターによって算出される。

\section{3 自㨁㾟取機}

従来は磁探機で表面战部に戴った磁粉を作業者 が目視でマークし，その後疵取でマーク部を捜し 手直しを行っていた。したがって，マーク部の見 逃しや症取残しばかりでなく疵取探さや疵取形状 などに個人差があり，品質保証上問題が発生して いた。これを前述の自動磁探譏システムと直結す ることにより解決した。本装居（写真2）は以下 の特徽を持つ。

（1）瘷取へッド重量の軽量化及び機能集約によ る高速処理 
表 2 設俑の主仕様

\begin{tabular}{|c|c|c|}
\hline & 項 & 仕 \\
\hline \multirow[t]{4}{*}{ 被 } & 検 査 材 & 熱間圧延仕上げ丸棒釦 \\
\hline & 鍼連 & 特殊銓全般（非磁性销を除く） \\
\hline & 寸法・長さ & $\phi 20 \sim 55 \times 3.5 \sim 7.2 \mathrm{ml}$ \\
\hline & 表面性状 & ショットブラスト，2ロール知正肌 \\
\hline \multirow{2}{*}{ 熊 } & 処理サイクルタイム & 6 秒/本 \\
\hline & 㾟検出能 & $0.1 \mathrm{~mm}$ 深さ $\times 20 \mathrm{~mm}$ 長さ \\
\hline \multirow{5}{*}{$\begin{array}{l}\text { 自 } \\
\text { 動 } \\
\text { 磁 } \\
\text { 㗎 } \\
\text { 譏 }\end{array}$} & $\mathrm{CCD} カ \rtimes$ & 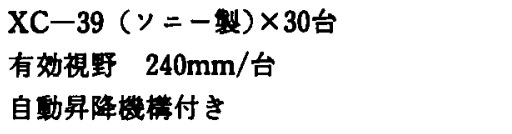 \\
\hline & 硪化柿嘈 & 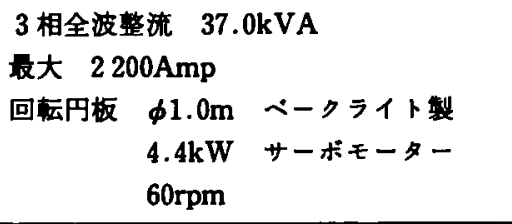 \\
\hline & 㾟見ローラー & $\phi 100 \mathrm{~mm} \quad 4.5 \sim 8.2 \mathrm{rpm}$ \\
\hline & 画像処理凌嘈 & 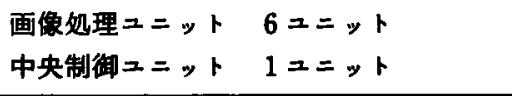 \\
\hline & 磁粉 & 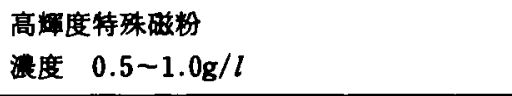 \\
\hline & 自動疵取機 & 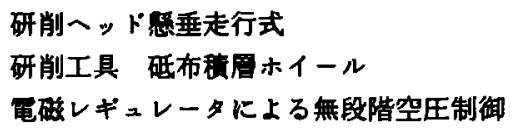 \\
\hline
\end{tabular}

〈磁化・磁粉液散布啳〉

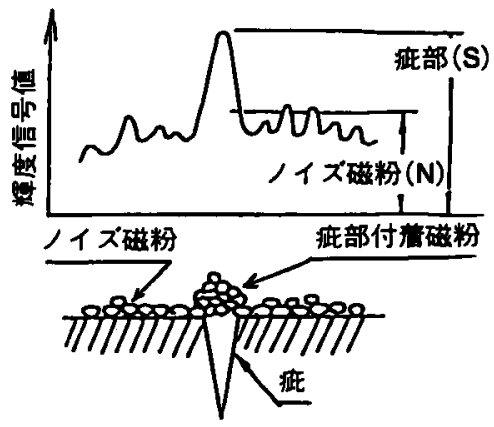

〈水洗処理啳〉

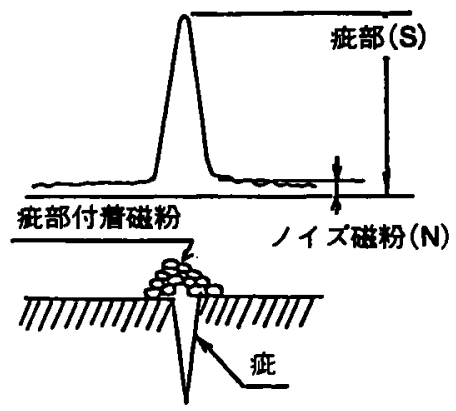

図 3 水洗処理効果

（2）砥布穔首研削ホイール採用による症取形状 の改善
（3）ホイール王着力の無段階制御によるシビフ な疵取深さコントロールが可能 


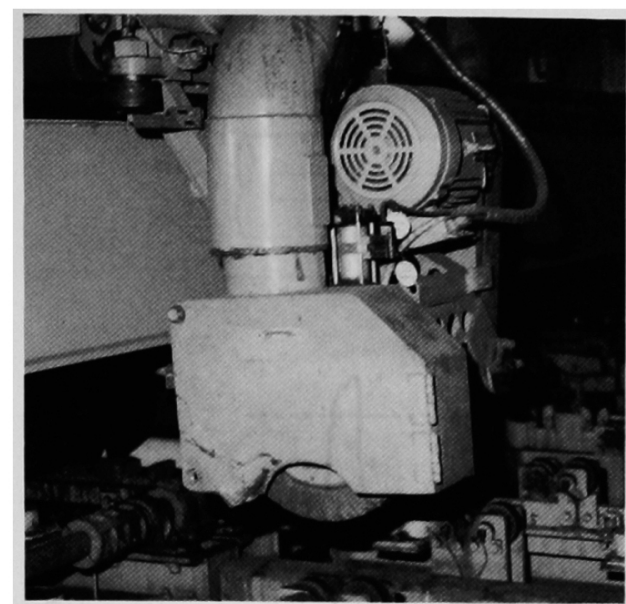

写真 2 自動㾟取機

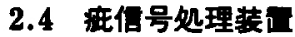

\subsection{1 画偆処理 部}

$\mathrm{CCD}$ カララで撮像された被検査材礠粉模様の 輝度を解析し，設定されたしきい值(判定レペル) を超えた何号を疵と判定し，中央制御部へ后送す る機能を持つ。画像処理ユニットは 1 台で 5 台の

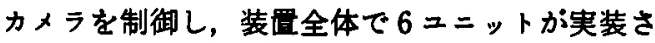
れている。また，撮像画面全体を検査情報として とらえると，被検查材以外の部分やブラックライ トの反射光部す検出するため，適正に探偒籍囲を 設定するウインドウ機能を持ち，安定した瘷検出 性能が維持できるよ5配虑している。

\subsection{2 中央制御部}

中央制御部は画像処理ニニットから伝送される 疵検出情報を整理して症マップを作成し㭘查・痽 取ブロコンへ看送する。また，疵取プロコンから 公送されてくる製品情報を受け，シーヶンサや磁 化龟源部一探传条件を指示する機能を持ち，装置 全体をコントロールしている。

\subsection{3 検圭・淑取プロコン}

検查・疵取プロュンは検查ランクなどのロッ ト・製品情報を中央制御部人伝送すると供に，中 央制卸部から伝送された症マッブを基に㾚のクル 一ブ化と研削順を決定して疪取マップを作成し， シーヶンサに研削位专・研削順・研削压を指示す る機能を持っている。

\section{3. 㾔湌出方法}

\section{1 模出原理}

図 4 に示すよ5に, CCD メラから撮像された 輝度に比例した奄压信号が $0 \sim 12 \mathrm{~V}$ で出力され， しきい值（判定レペル）は0－12Vの255等分つま り256通りのレペルで壬意に設定できる。

しきい値を招える奄压信号を“1”，しきい值よ り低い龟圧信号を“0”として処理し（二値化処 理）“1”の集まりを症信号として見なす。しかし， 二值化された症ドット（dot）“1”が一つでああ れば㾟として処理すると，磁粉液のしずくなどの 真の痽以外のノイズ磁粉も全て検出してしま5た め，二值化処理後にフィルター回路を設け瘷の連 続性をチェックすることにより誤検出防止を図っ ている。

本装置では安定した摷業を行らため, CCD メ ラからの奄圧信号がしきい值を連続して12dot(約 $20 \mathrm{~mm}$ ）以上超える場合を揤として処理するよう にフィルターが設定されている。また，検出可能 な瘷長さはこのフィルタ一の設定值を変更するこ とで任意に設定できるシステムになっている。

\section{2 掂長さ・位貫橉正}

検出した瘷の長さと端面からの位置補正は图 5 に示す方法で行っており，フィルターでカットし た $20 \mathrm{~mm}$ 相当分の補正を行っている。

\section{3 自己診断機能}

ブラックライトの紫外線強度のハララッキやカメ ラの感度ハラッキ，あるいは䂭洨度などの探 稘性能に大きく影翌する探㬐条件に対し総合的に 探傷感度の補正を行うのが目的で，カメラごとに 被検查材ハックグランド輝度を測定し，その測定 値を基準にカメラごとに感度を自己調整する機能 である。

\section{4. 症模出性能}

図 6 の㾟深さことと疵検出性能から判るよら に，本装贯では深さ0.1mm の表面㾟（長さ $20 \mathrm{~mm}$ 以上）を100\%の検出率で精度良く検出しており， 漏洩磁束探伤法以上の症検出性能であることが分 かる。また，その検出事例を写真 3 に示す。

5. おわ わに

自動車・産業機器などの需要家は各業界の熾烈 

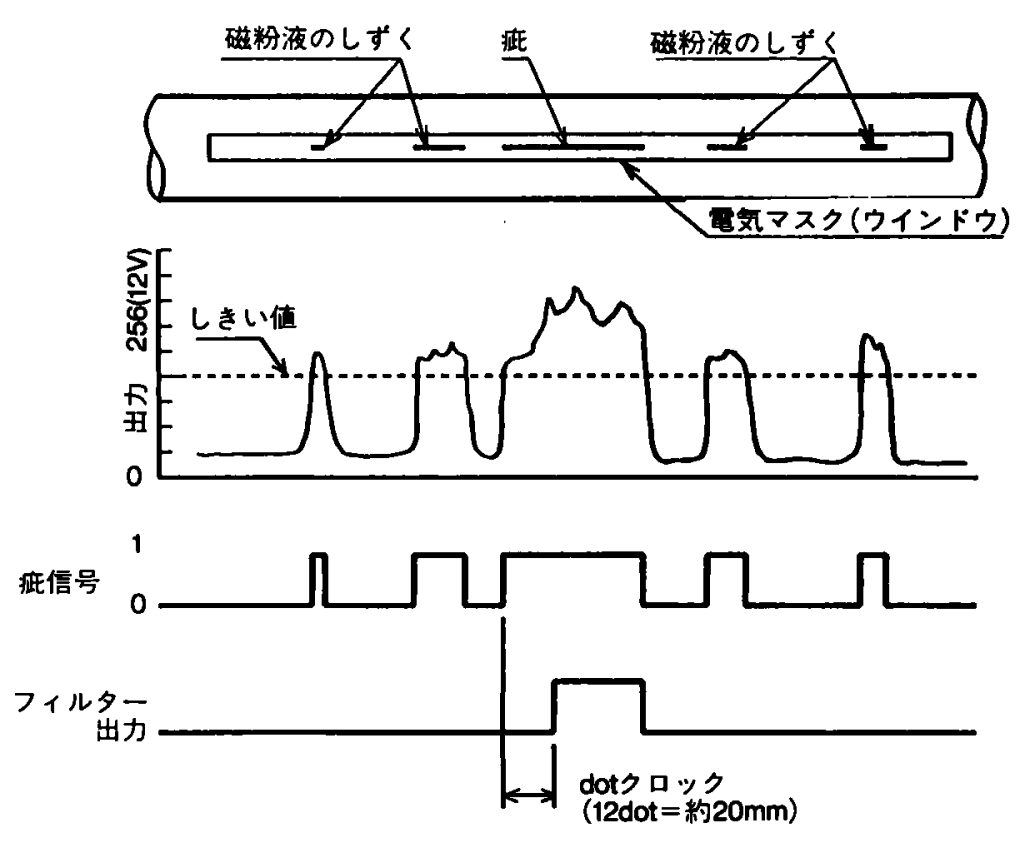

図 4 疵検出原理

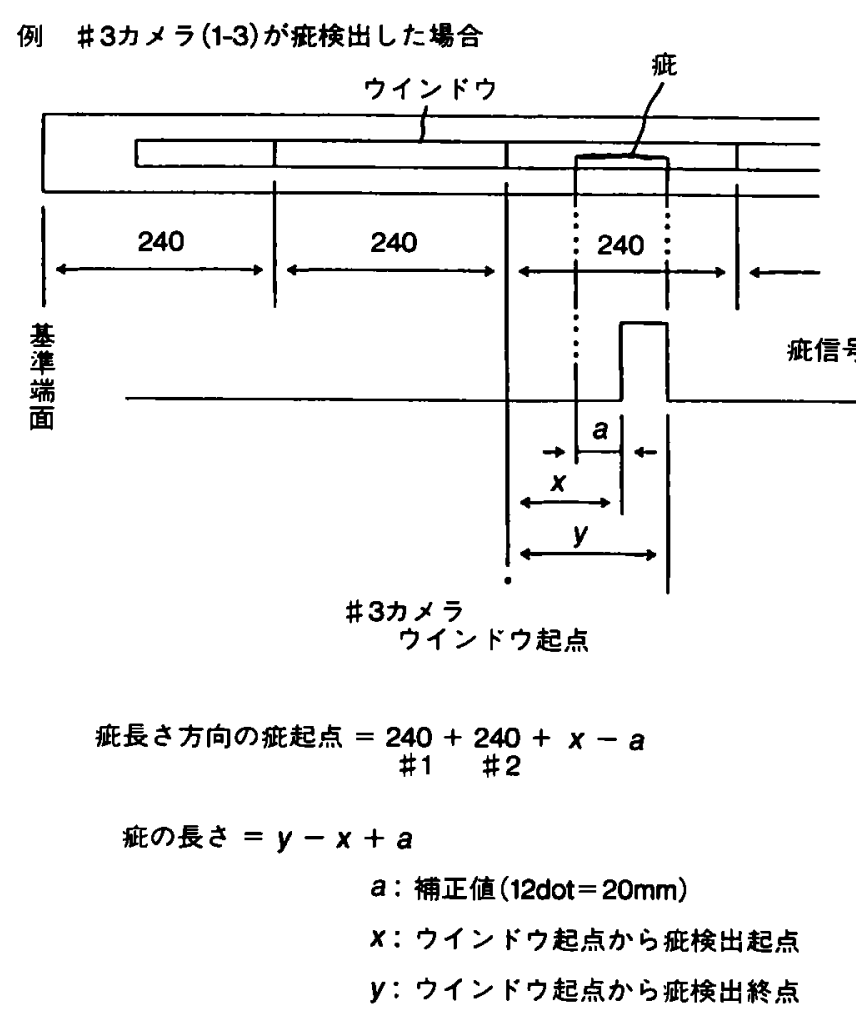

因 5 疵長さと疵位罡の補正 


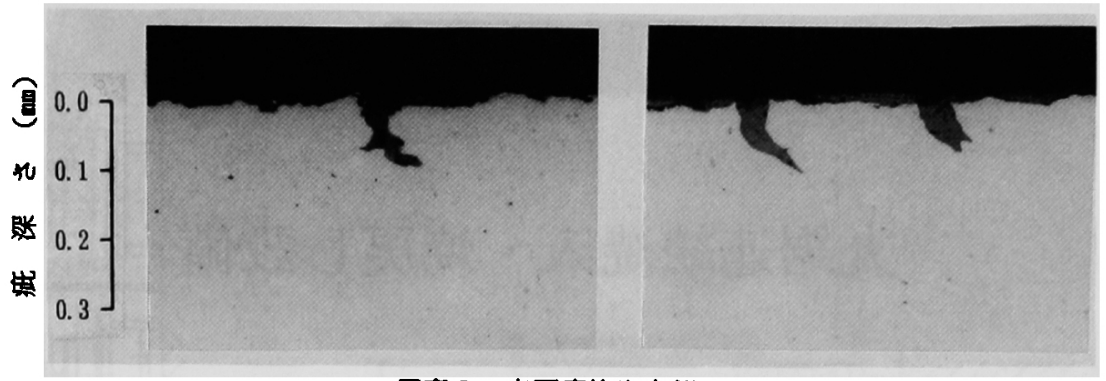

写真 3 表面痏検出事例

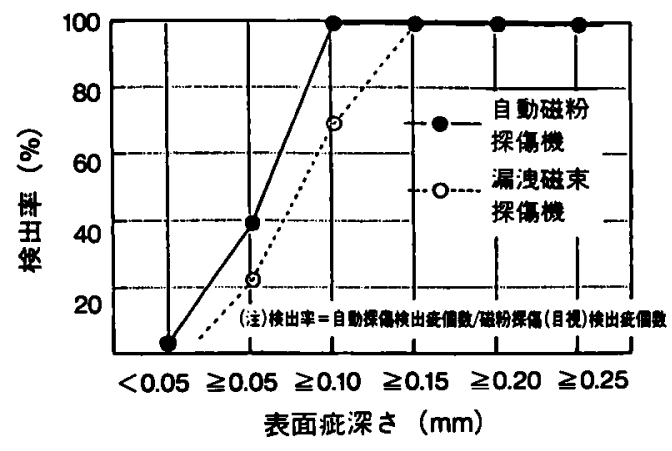

因 6 症検出性能

な競争の中で，歩留り向上・省工程などの原価低 減指向及び生産性向上の観点から素材において ppm オーダーの不良率でさえ許容されないパー フェクトな品質を要求している。それ故今後我々 は,さらに高精度な検查機器の開発及び自動化に よるパーフェクトな品質保証はもちろんのこと， 鋼材製造工程での品質造り込み技術向上のため製 造部門への迅速な品質情報提供がますます重要に なってきており，これら実現のためさらに努力を 続けて行く所存である。

(文 献）

1）石田二郎：電気製鋼，60 (1989) 1,66

2）那須田，中山：奄気製鋼，61 (1990) 1, 55

3）香田 浩：電気製鋼，62 (1991) 3, 224 